\title{
Database analysis of a computational model of an elemental oscillator in the leech heartbeat neuronal network Anca Doloc-Mihu* and Ronald Calabrese
}

\author{
Address: Emory University \\ Email: Anca Doloc-Mihu* - adolocm@emory.edu; Ronald Calabrese - ronald_calabrese@emory.edu \\ * Corresponding author
}

from Eighteenth Annual Computational Neuroscience Meeting: CNS*2009

Berlin, Germany. 18-23 July 2009

Published: 13 July 2009

BMC Neuroscience 2009, 10(SuppI I):P263 doi:I0.II86/I47I-2202-I0-SI-P263

This abstract is available from: http://www.biomedcentral.com//47I-2202/I0/SI/P263

(c) 2009 Doloc-Mihu and Calabrese; licensee BioMed Central Ltd.

\section{Background}

The rhythmic activity of the heartbeat neuronal network of the leech is based on pairs of inhibitory interneurons that make reciprocal spike-mediated and graded synapses across the ganglion midline [1]. In this work, we modeled such a pair of $\mathrm{HN}(4)$ reciprocally inhibitory interneurons (Figure 1) with a half-center oscillator (HCO) model. We aim to investigate the changes in this model's oscillatory activity and bursting characteristics based on cellular and synaptic parameters. To achieve this, we varied selected parameters in all combinations by using a brute-force approach and built a database of the resulting model characteristics following earlier work $[2,3]$.

\section{Methods}

We represented the individual neurons as single isopotential compartments with Hodgkin and Huxley type intrinsic and synaptic membrane conductances. The model differential equations were integrated by using the exponential Euler method with a time step of $0.1 \mathrm{~ms}$ [1]. For our parameter search, we varied eight parameters in both neurons: the maximal conductances of the spike-mediated synapse, graded transmission synapse, and of the persistent $\mathrm{Na}^{+}$, slow $\mathrm{Ca}^{2+}$, leak, hyperpolarization-activated (h), and persistent $\mathrm{K}^{+}$currents, across of $0,25,50,100$, 125,150 , and 175 percent of their canonical values, and the leak reversal potential across $-0.07 \mathrm{~V},-0.065 \mathrm{~V},-0.06$ $\mathrm{V},-0.055 \mathrm{~V}$, and $-0.05 \mathrm{~V}$, resulting in a parameter space of $10,485,760$ models. After changing a parameter, a model was run for $100 \mathrm{~s}$ to allow the system to establish stable activity, and then, it was run for another $100 \mathrm{~s}$, from which the data were recorded and analyzed. The cycle period was measured as the time between the middle spikes of two consecutive bursts. The HCO model was classified as either bursting, spiking or silent.

\section{Results}

We performed all the simulations. However, as a preliminary step in the analysis of the model database, we selected a random subset of 10,000 simulations from the entire set, for which we build a SQL database table $[2,3]$. Approximately $37 \%$ of these simulations have both cells as being silent, $30 \%$ of them have both cells spiking, and $17.5 \%$ have both cells bursting with standard alternating $\mathrm{HCO}$ activity. The rest of the simulations do not have symmetric activity in the two model cells. We will now use this sample and then the entire database to ask fundamental questions about HCO activity. For example, we will subdivide the bursting HCOs in to those in which the component cells are intrinsically silent, spiking or bursting, and then, ask whether oscillators of these different types respond to parameter changes similarly. We will be particularly interested in parameter changes that correspond to known neuromodulations such as the modulation ofh current by myomodulin [4].

\section{Acknowledgements}

This work was supported by the National Institute of Neurological Disorders and Stroke Grant NS024072 to R.L.Calabrese. 


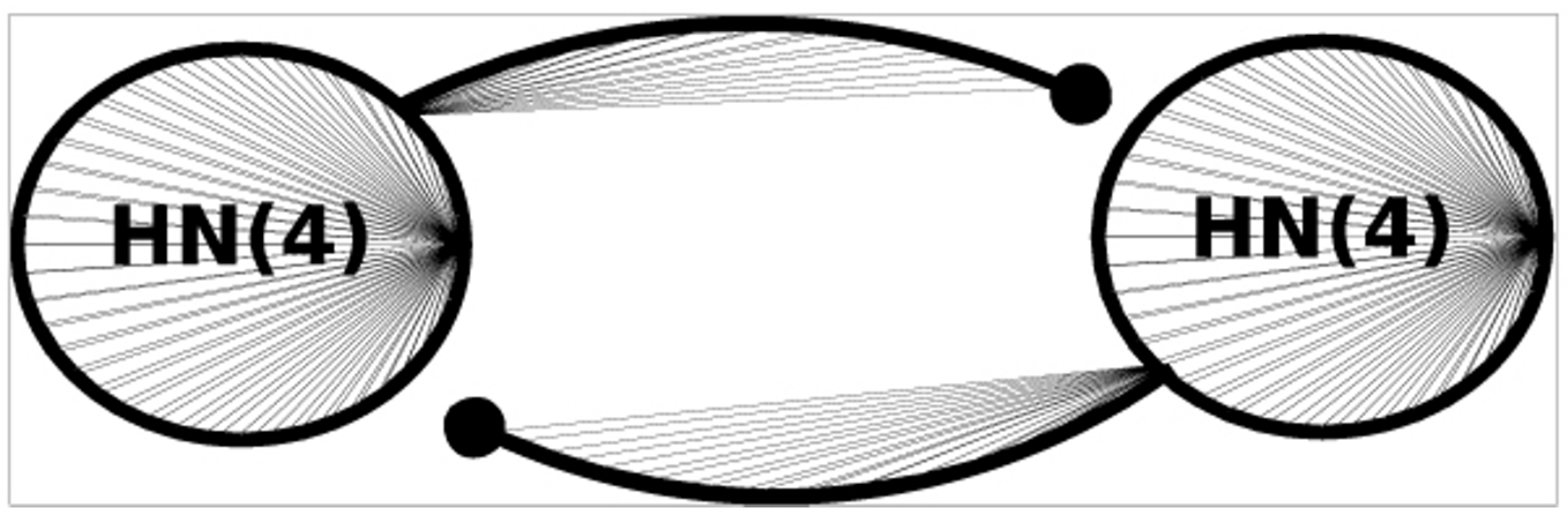

Figure I

Elemental Oscillator Model.

\section{References}

I. Hill AAV, Lu J, Masino MA, Olsen OH, Calabrese RL: A model of s segmental oscillator in the leech heartbeat neuronal network. J Comp Neurosci 2001, 10:281-302.

2. Prinz A, Billimoria CP, Marder E: Alternative to hand-tuning conductance-based models: construction and analysis of databases of model neurons. J Neurophysiol 2003, 90:3998-40I5.

3. Gunay C, Edgerton JR, Jaeger D: Channel densitydistributions explain spiking variability in the globus pallidus: a combined physiology and computer simulation database approach. J Neurosci 2008, 28:7476-749I.

4. Tobin AE, Calabrese RL: Myomodulin increases Ih and inhibits the $\mathrm{Na} / \mathrm{K}$ pump to modulate bursting in leech heart interneurons. J Neurophysiol 2005, 94:3938-3950.

Publish with Bio Med Central and every scientist can read your work free of charge

"BioMed Central will be the most significant development for disseminating the results of biomedical research in our lifetime. "

Sir Paul Nurse, Cancer Research UK

Your research papers will be:

- available free of charge to the entire biomedical community

- peer reviewed and published immediately upon acceptance

- cited in PubMed and archived on PubMed Central

- yours - you keep the copyright
BiolMedcentral 